\title{
MEDINDO O GRAU DE INOVAÇÃO NAS MICRO E PEQUENAS EMPRESAS NO NORDESTE DO BRASIL
}

\author{
C.E.WALTER ${ }^{*}$, C.M. VELOSO, P.O. FERNANDES \\ Instituto Federal de Educação, Ciência e Tecnologia do Piauí \\ eduardowalter@ifpi.edu.br*
}

Artigo submetido em 12/03/2018 e aceito em 05/09/2018

DOI: $10.15628 /$ holos.2019.7080

\section{RESUMO}

As empresas não operam em total isolamento do meio em que estão inseridas. $O$ entorno ao mesmo tempo em que é influenciado pelas organizações influencia na conduta e desempenho das mesmas, sobretudo, no que diz respeito à prática da inovação. As pequenas e médias empresas são o motor do desenvolvimento económico, principalmente em países em desenvolvimento como o Brasil. Nessa conformidade, o principal objetivo desta pesquisa foi apresentar e testar um modelo de pesquisa de inovação em Micro e Pequenas Empresas proposto por Walter, Veloso e Fernandes (2017) para analisar: (1) o grau de inovação das Micro e Pequenas Empresas e (2) como a inovação é apresentada nas Micro e Pequenas
Empresas como resultado de seus ambientes de negócios. Para isso, o estudo baseou-se em uma amostra de 617 MPE distribuídas em 6 cidades do Estado do Piauí. Os dados foram coletados através da aplicação do Radar de Inovação. Foram utilizadas técnicas estatísticas de natureza descritiva, exploratória e inferencial. Os resultados mostraram que as MPE têm capacidade de inovação entre "Pouco Inovadoras" e "Inovadoras Ocasionais", devido à maior expressividade de inovações organizacionais e de marketing, e que a média e a distribuição da inovação são as mesmas entre as MPE analisadas.

PALAVRAS-CHAVE: Micro e Pequenas Empresas, Índice Global Médio de Inovação, Inovação, Gestão, Brasil.

\section{MEASURING THE DEGREE OF INNOVATION IN MICRO AND SMALL ENTERPRISES IN THE NORTHEAST OF BRAZIL}

\begin{abstract}
The companies don't operate in total isolation from the environment in which they are inserted. The environment at the same time as it is influenced by the organizations, in the performance and the performance of its origins, especially with regard to the practice of innovation. Small and medium-sized enterprises are the engine of economic development, especially in developing countries such as Brazil. Accordingly, the main objective of this research was to present and test a research model of innovation in Micro and Small Enterprises (MSE) proposed by Walter, Veloso and Fernandes (2017) to analyze: (1) the degree of innovation of Micro and Small Enterprises and (2) how the innovation is presented in the Micro and Small
\end{abstract}

Enterprises as a result of its business environments. For this the study was based on a sample of 617 MSE distributed in 6 cities of the State of Piauí. The data were collected through the application of the Innovation Radar. Statistical techniques of descriptive, exploratory and inferential nature were used. The results showed that MSE have innovation capacity between "Little Innovative" and "Occasional Innovative", due to the greater expressiveness of organizations and marketing innovations, and that the average and the distribution of innovation are the same among MSE analyzed.

KEYWORDS: Micro and Small Enterprises, Global Average Index Innovation, Innovation, Management, Brazil. 


\section{INTRODUCTION}

The companies don't operate in total isolation from the environment in which they are inserted. The environment at the same time as it is influenced by the organizations determines the conduct and performance of the same, especially, with respect to the practice of innovation. Small and medium-sized enterprises are the engine of economic development, especially in developing countries. To respond to changing market circumstances, companies need to develop their organizational capacities, defined as the execution of coordinated tasks and the use of resources in order to reach a predetermined end (Inan \& Bititci, 2015).

According to the Oslo Manual (OCDE \& FINEP, 2005), several exogenous factors make up the innovation scenario in the developing countries, such as macroeconomic uncertainty, instability, institutional fragility, lack of social awareness about innovation, entrepreneurial nature of risk aversion, lack entrepreneurs, barriers to nascent businesses, lack of public policy instruments to support business and managerial training, which act as an obstacle to innovation activity in these countries, a fact also pointed out by Rojas and Carrillo (2014), by showing that the exposure of Latin American Countries with weak administrative, commercial and productive structures to market failures has led to defensive innovation strategies that take precedence over production initiatives and technological dominance with a more strategic focus.

Given the importance attributed to innovation, the current research has the main objective to present and test a research model of innovation in Micro and Small Enterprises for developing countries proposed by Walter, Veloso and Fernandes (2017). In such a manner to verify how the innovation presents itself in the MSE of the State of Piauí, considering that innovation is now considered the key to obtaining competitive advantages, creating positive results both for the companies involved in the innovation process and for the economy as a whole.

The choice of the State of Piauí as object of study of the present investigation was motivate by the high number of businesses opened in the years of 2014 and 2015, of which more than $85 \%$ of the total were characterize as Micro and Small Enterprises, according to the Board of Trade of Piauí (JUCEPI, 2015).

Besides this brief introduction, the article is structure in four points. The following is the framework of the study, where the main concepts that guided the research will be presented. Subsequently, the conceptual model and the research hypotheses will be presented. Next, the methodology and the analysis of the results will be presented, being this the core of the present investigation and, finally, the contributions of the accomplishment of this investigation.

\section{THEORETICAL FRAMEWORK}

\subsection{A brief introduction about innovation and its importance}

According to Hamel and Sayago (2007), innovation is a systemic capacity constituted through training, tools, evaluation criteria, inventive decision processes and organizational values. For 
Paredes, Santana and Fell (2014), innovation can be considered an instrument that can be used by entrepreneurs to explore change as an opportunity to differentiate a business or a service. It can also be understood as an asset composed of several elements that help and develop the sustainability of the company's relationship with its clients.

In the design of Tigre (2006), innovation is the effective practical application of an invention, which refers to the creation of a process, technique or product unprecedented. It can be disseminated through technical and scientific articles, registered in patent form, viewed and simulated through prototypes and pilot plants without, however, having an effective commercial application. Another important insight on innovation can be found in Kim and Mauborgne (2005). The concept of innovation for these authors is extended. It speaks of "value innovation", called the strategy that encompasses the whole system of activities of the company. Since the value to consumers stems from the utility and price of the products and services and the value to the company results from the price compared to the costs, value innovation is only achieved when the entire system of activities of the company, involving utility, price and cost align properly.

Bayarçelik et al. (2014, p.203) argue that "innovation can only occur if there is a capacity for innovation in the enterprise. Innovation capability refers to the availability of resources, collaborative structures, and problem-solving processes". In addition, they further state that "successful innovation can be achieved through an integrated development of business strategy and market positioning of the company, work organization, technology and people" (p.203), taking into account factors institutional factors, technological capacities, consumer preferences, economic factors, cultural factors, management skills, learning abilities, market orientation and gaining competitive advantage.

According to Akis (2015, p.1320), "whatever the type and concept of innovation adopted, it increases the productivity of enterprises at the micro level, reducing their costs, improving their profits and improving the capacity of employees". This is corroborated by Ceretta, Reis and Rocha (2016, p.434), stating that "innovation is one of the fundamental tools in growth strategies to enter new markets, increase market power and provide the organization with competitive advantages".

\subsection{The configuration of innovation in Micro and Small Enterprises}

The creation and implementation of innovations requires a proper, educated and creative team. The capacity for innovation in most ventures lies in the knowledge, experience and skills of employees and managers. In Micro and Small Companies, these elements don't exist sufficiently, hindering innovation (Skibinski \& Sipa, 2015).

MSE have characteristics such as the involvement of leaders in operational activities, focus on short-term and survival plans, low standardization and formalization, limited client base, low level of employee training, limited knowledge of operational activities improvement and, especially innovation based on the needs of improvement and technological clients (Inan \& Bititci, 2015).

For Sibirskaya, Stroeva and Simonova $(2015$, p.510) "the advantages of small innovative enterprises are flexibility, the ability to adapt to the new demands that have been made by scientific and technical progress". 
Ornek and Ayas (2015) point to a positive relationship between intellectual capital and corporate performance, a relationship that is embodied in the transfer of intellectual capital to innovation. Therefore, the importance of the detention of qualified individuals is evidenced, as well as the existence of mechanisms that help in the development of innovations through the identification, use and sharing of knowledge, and since the MSE have low degree of training of the collaborators, innovation in these ventures may be undermined.

According to some authors (e.g. Schreiber et al., 2013; Reichert et al., 2015; Tigre, 2006; Paula, 2014; Rojas \& Carrillo, 2014), MSE generally don't have the capacity for product innovation, and when they innovate in this factor is to respond to a market demand. The products are only significantly improved, which strictly is considered as an incremental innovation, that is, that there is no great break with the standard of innovation until then in force. There are no significant investments in R\&D for the development of new products, so that it can be said that with regard to the product the MSE adopts a traditional innovation strategy.

Regarding process innovation, Reichert et al. (2015), Pereira et al. (2009), Rojas and Carrillo (2014) and Demonel and Marx (2015) point out that the lack of R\&D investments and the difficulty of obtaining credit negatively affect this type of innovation in MSE, causing them to establish a relationship of dependence on machines and equipment of third parties, also using them in a way incremental.

In contrast to these weaknesses, MSE have great potential for organizational and marketing innovation, because they have a flexible and lean structure, which can lead to less resistance to new ways of organizing the workplace, new forms of decision and action and new business processes (Taborda et al., 2013; Rodrigues, 2003; Paula, 2014; Schreiber et al., 2013; Demonel \& Marx 2015; Sibirskaya, Stroeva \& Simonova, 2015).

\section{CONCEPTUAL MODEL AND RESEARCH HYPOTHESES}

The Figure 1 presents the conceptual research model proposed by Walter, Veloso and Fernandes (2017) to evaluate how innovation presents itself in MSE. The proposed model was developed based on recommendations of the Oslo Manual (OCDE \& FINEP, 2005), considering innovation as a system of interactions and interdependencies.

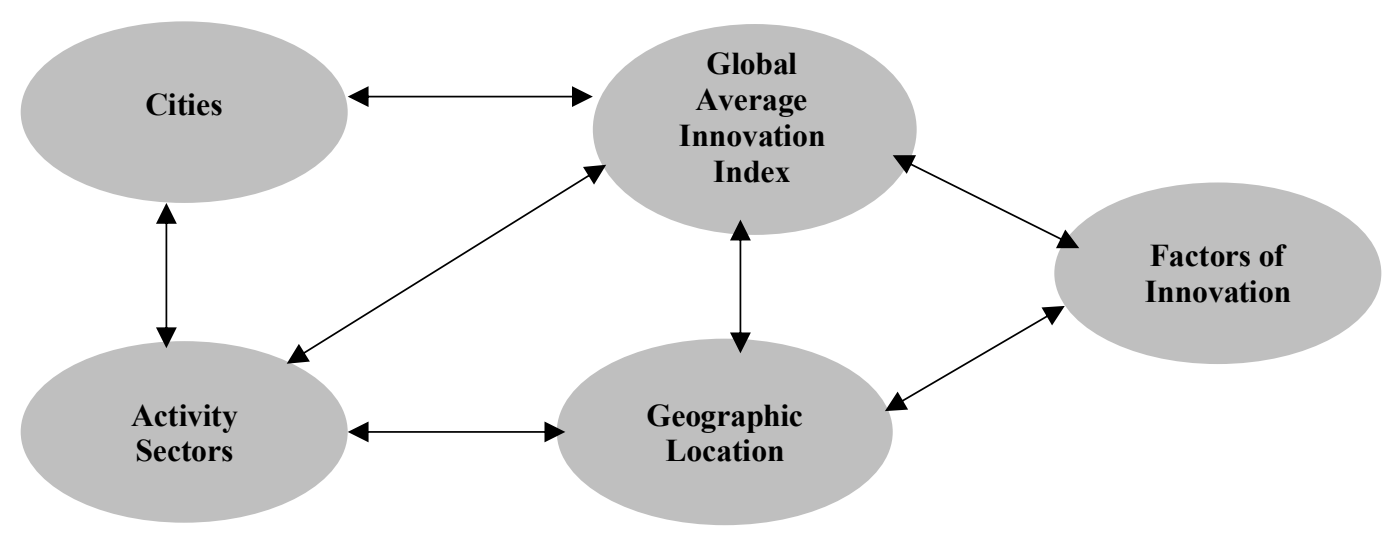


Figure 1- Research Model proposed by Walter, Veloso and Fernandes (2017).

The justification of the model is based on Skibinski and Sipa (2015). They claim that MSE because they have limited internal resources should make use of external knowledge sources. In this way, the ability to exploit and use the knowledge that comes from abroad becomes a key element and predictor of successful innovation, which makes the environment in which they are located and the development of appropriate tools to exploit it. The general and classic models of innovation presented by Rothwell (1994) define innovation as a set of processes that should be undertaken by the organizations in isolation for the development of innovations, especially in the development of new products. Recent models of innovation such as Cooper (1988), Khurana and Rhosental (1997), Koen et al. (2001), Flynn et al. (2003), Boeddrich (2004), Reid and Brentani (2004), Whitney (2007), Brem and Voigt (2009) and Kurkkio et al. (2011), besides being strictly theoretical, focused on large companies and on processes that companies must undertake in isolation, they also emphasize the development of products to the detriment of the development of other types of innovation, such as services, processes, marketing and organizational.

The theoretical model presented in this paper differs from the models listed by:

I. being a model that seeks to investigate how the degree of innovation is configured to the detriment of the business environment, having a more comprehensive perspective than the company object alone, as is the case with the above-mentioned models;

II. to characterize itself as a suitable model for the investigation of innovation in Micro and Small Enterprises by presenting a system of interactions between Micro and Small Enterprises and their business environments, thus enabling the investigation of the degree of innovation according to location geographical;

III. to provide information on Micro and Small Enterprises innovation in a global way, not limited solely to the development of products.

Accordingly, with the main objective of testing the conceptual model presented in Figure 1, the following research hypotheses are established:

$\mathrm{H}_{1}$ : The Micro and Small Enterprises of the State of Piauí present themselves as little innovative.

The conceptual framework of the research hypothesis 1 is based on Demonel and Marx, (2015); Reichert et al. (2015) and Taborda et al. (2013), because they say that innovation in MSE entails greater difficulties related to lack of resources, scarce or non-existent investments in Research and Development (R\&D), strong dependence on technology acquisition (Machinery and equipment) and limited managerial capacities. Nevertheless, in developing countries (DC), as Rojas and Carrillo (2014) point out, market failures such as imperfect competition, externalities and information asymmetries have a negative impact on companies' capacity for innovation, that they assume defensive and merely reactive strategies

$\mathrm{H}_{2}$ : Innovation in Micro and Small Enterprises in the State of Piauí presents itself differently due to its business environments (geographical location and sectors of activity). 
$\mathrm{H}_{2.1}$ : The Global Average Innovation Index is different for cities;

$\mathrm{H}_{2.2}$ : The Global Average Innovation Index is different for the activity segments;

$\mathrm{H}_{2.3}$ : The Global Average Innovation Index is different for geographic location.

The conceptual framework of the research hypothesis 2 is based on Aarstad et al. (2016), since they point to the geographic environment as an important factor influencing growth, profits and business development, including survival and innovation performance. In this sense, as established by Skibinski and Sipa (2015), innovation in MSE may be associated with its ability to explore and use the knowledge that comes from its environment.

\section{METHODOLOGY}

The instrument used for data collection was a questionnaire survey. The instrument is composed of 32 items that evaluate 13 dimensions of the innovation, resulting from an adaptation made by Bachmann (2011) for application in MSE of the Innovation Radar, of Sawhney et al. (2006), originally constituted of 12 (Twelve) dimensions. The innovation dimensions assessed by the Innovation Radar are: (1) Supply; (2) Platform; (3) Brand; (4) Customers; (5) Solutions; (6) Relationship; (7) Value Aggregation; (8) Processes; (9) Organization; (10) Supply Chain; (11) Presence; (12) Network and (13) Innovative Ambience.

Each dimension was measured using an ordinal scale ranging from 0 (zero), when the measured item was totally absent at 5 (Five), which meant that the item was fully present. In order to evaluate the reliability or internal consistency of the scale referring to the 13 (thirteen) dimensions of Innovation Radar, the Cronbach's Alpha was calculated as a measure of the proportion of variability in responses (Maroco \& Marques, 2006). Obtaining a Cronbach's Alpha of 0,771 , which can be considered as a reasonable reliability, being between 0,7 and 0,8 .

The study was conducted with a sample of 617 Micro and Small Enterprises of the State of Piauí, Brazil. For the treatment, analysis and interpretation of the data were used the software SPSS Statistics in its version 22 and Numbers in its version 3.1. The statistical techniques used were descriptive, exploratory and inferential in order to describe, analyze and interpret the behavior of the attributes under study. Thus, in the first phase we chose to calculate the Global Average Innovation Index (GAII), obtained by means of the simple arithmetic mean of the above mentioned 13 (Thirteen) dimensions of Innovation Radar (Equation 1).

$$
G A I I=\frac{1}{n} \sum_{i=1}^{n} X_{i}
$$

where,

$n$, corresponds to the number of independent variables of the Innovation Radar;

$X_{i}$, corresponds to the independent variables of the Innovation $\operatorname{Radar}(i=1, \ldots, 13)$ 


$$
G A I I=\frac{1}{13} \sum_{i=1}^{13}\left(X_{1}+X_{2}+X_{3}+X_{4}+X_{5}+X_{6}+X_{7}+X_{8}+X_{9}+X_{10}+X_{11}+X_{12}+X_{13}\right)
$$

At where,

$X_{1}$, Supply; $X_{2}$, Platform; $X_{3}$, Brand; $X_{4}$, Customers; $X_{5}$, Solutions; $X_{6}$, Relationship; $X_{7}$, Value Aggregation; $X_{8}$, Processes; $X_{9}$, Organization; $X_{10}$, Supply Chain; $X_{11}$, Presence; $X_{12}$, Network; $X_{13}$, Innovative Environment.

The population of this present investigation are 120.156 MSE. A sample error of 3,94\% and a significance level of $5 \%$ was assumed to calculate the sample size, that was determined through sample simple aleatory.

In order to make the decisions regarding the different hypotheses of investigation, a level of significance of $5 \%$ was assumed throughout the analysis.

\section{ANALYSIS AND PRESENTATION OF RESULTS}

The study sample consists of 617 MSE distributed among six cities in the State of Piauí, as follows: Teresina 425 (68,9\%); Bom Jesus 47 (7,6\%); Floriano 40 (6,5\%); Piripiri 40 (6,5\%); Picos 33 $(5,3 \%)$ and Parnaíba 32 (5,2\%). Regarding the distribution of MSE by activity sectors, it is estimated that $54,6 \%, 34,5 \%$ and $10,9 \%$ represent the Services, Commerce and Industry segments, respectively. Regarding the location, $68,9 \%$ of the MSE in the sample are in the state capital, while $31,1 \%$ are located in the interior of the State.

In order to answer the first research hypothesis, the Global Average Innovation Index (GAII) was calculated by means of the simple arithmetic mean of the 13 dimensions of the Innovation Radar. The overall mean value was 2,01 points (deviation standard of 0,92), denoting globally that the MSE of the study sample have innovation capacity between "Little Innovative" and "Occasional Innovative". According to the adapted classification of Neto and Teixeira (2011), in which the final average score 1 (One) means "Little Innovative"; The final average score 3 (Three) means "Occasional Innovative" and the final average score 5 (Five) means "Systemic Innovative". The mean standard deviation of 0,92 indicates that the firms analysed responded to questions related to the Innovation Radar in the same sense, that is, there was little variability around them.

The value obtained from the Global Average Innovation Index (GAII) can be explained by the greater expressiveness of the types of organizational and marketing innovation in the MSE studied.

It was found that the Platform dimension, average of 3,27 (standard deviation of 1,54), which evaluates the ability of companies to use the same resource structure to offer different products/services can be considered as a form of organizational innovation. Accordingly, the average upper value presented in this dimension is in accordance with what is commonly observed in the literature on innovation in MSE (e.g., Taborda et al., 2013; Demonel \& Marx, 2015; Sibirskaya et al., 2015). Since they have greater potential for organizational innovation because they have flexible organizational structures, which can lead to less resistance to new forms of decision-making processes and new business processes.

In the Supply dimensions, mean of 2,33 (standard deviation of 1,06); Brand, mean of 2,75 (standard deviation of 1,02); Customers, mean of 2,09 (standard deviation of 0,84); Relationship, 
mean of 2,51 (standard deviation of 1,21), and Network, with a mean of 2,16 (standard deviation of $1,31)$, the type of innovation is Marketing.

Once again, it was verified that the average values obtained are in agreement with the literature on the subject (e.g., Rodrigues, 2003; Pereira et al., 2009; Paula, 2014). Since although many MSE do not understand core marketing concepts as a positioning and do not fully understand the markets in which they operate, they have great potential for innovation in Marketing because they are in close proximity to their customers, and in this way they can develop new forms of relationship and obtain inputs for the development of new products and services of value.

The dimensions with lower average values: Solutions (Product Innovation), mean of 1,68 (standard deviation of 0,91); Value Aggregation (Marketing Innovation), mean of 1,47 (standard deviation of 0,78 ); Processes (Process Innovation), mean of 1,50 (standard deviation of 0,43 ); Organization (Organizational Innovation), average of 1,75 (standard deviation of 0,71); Supply Chain (Organizational Innovation), mean of 1,59 (standard deviation of 0,96); Presence (Marketing Innovation), mean of 1,37 (standard deviation of 0,75 ); and Innovative Environment (Organizational Innovation), average of 1,63 (standard deviation 0,48 ), represent types of innovation that require a greater analytical capacity, are more technical innovations that require experience and skill on the part of employees and managers. According to the literature on the subject (e.g., Schreiber et al. (2013); Reichert et al., 2015; Tigre, 2006; Paula, 2014; Rojas and Carrillo, 2014; Pereira et al., 2009; Demonel \& Marx, 2015), in these enterprises these elements do not exist sufficiently, hindering innovation.

Since the MSE of the sample have a GAll of 2,01 points (standard deviation of 0,92 ), indicating that they are between "Little Innovative" and "Occasional Innovative", due to the preponderance of Organizational and Marketing Innovations, responding to research hypothesis 1, we intend to verify if there are differences in the GAll average for cities, geographic location and activity sectors to answer the research hypothesis 2 .

The verification of the existence of differences in the GAll average for the cities is done through the application of One-Way ANOVA. In order to be a parametric test, some assumptions need to be validated, namely if the variables follow the normal distribution in the different independent groups (using the Kolmogorov-Smirnov test), homogeneity of variances (Levene test), and Independency between groups, assuming a significance level of $5 \%$. Considering the normality test, Kolmogorov-Smirnov test, it was concluded that at a significance level of $5 \%$ there is enough statistical evidence to state that the study variable does not follow a normal distribution in the independent groups under study.

Given the violation of the first assumption for the application of the parametric test, the nonparametric alternative, in the case in question, was immediately applied to the Kruskal-Wallis test, in order to compare the GAll distributions in the six cities (Independent groups).

Using the Kruskal-Wallis test, considering that the obtained value was 0,303 , it can be concluded that there is no statistical evidence at the significance level of $5 \%$ to state that at least one of the GAll distributions is different for the six cities. 
In order to verify if there are differences in the GAll mean for the Geographic Location, the t-Student parametric test was used for two independent samples, whose application assumptions are normal population or $n \geq 30$ observations and unknown standard deviation.

However, once the sample size is different in both groups, the Levene test was applied to verify if the variances were homogeneous assuming a significance level of $5 \%$. From the results obtained it is concluded that there is not enough statistical evidence to affirm that the variances are significantly different for a level of significance of $5 \%$, since the obtained value was 0,375 , higher than the level of significance assumed. In relation to the t-Student, considering that the test value is 0,636 , higher than the level of significance assumed, it is concluded that there is enough statistical evidence to affirm that the average GAll is equal for the MSE of the interior and the capital to a level of significance of $5 \%$.

In order to verify if there are differences in the GAll mean for the Activity Sectors variable, once again the One-Way ANOVA is applied, which as previously mentioned is a parametric test in which the validation of the distribution assumptions must be verified normal in the different groups, homogeneity of variances and independence between groups. After verification of the normality assumption, the Kolmogorov-Smirnov test concluded that the study variable does not follow the normal distribution, by independent groups. In this regards there is a need to produce a nonparametric test, namely the Kruskal-Wallis test, in order to compare the GAll distributions for the Activity Sectors. For the values obtained by the Kruskal-Wallis test, given the value of evidence obtained and that was 0,821 , higher than the level of significance of $5 \%$, it can be said that there is no statistical evidence at the significance level of $5 \%$, to state that at least one of the GAll distributions is different for the Activity Sectors variable.

Based on what has been presented previously, it is concluded that the research hypotheses have not been validated, that is, since the Average Global Innovation Index obtained through the average of the 13 dimensions of the Innovation Radar applied in the 617 MSE of the State of Piaui was 2,01 points (standard deviation of 0,92 ), the MSE of the sample under study had an innovative capacity between "Little Innovative" and "Occasional Innovative", resulting in a non-validated research hypothesis 1 . However, because the GAll distribution is the same among cities, the GAll average is the same between the sectors of activity and for the geographical location, the research hypothesis 2 is not valid since there is sufficient statistical evidence to affirm that the innovation presents itself homogenized for the MSE of the study, using the control variables City, Activity Sectors and Geographic Location.

Šoltés and Gavurová (2014) argue that the effective development of innovation requires a functional innovation system composed of institutions, policies and tools to create conditions that promote innovation. After all the inferential analysis carried out, contrary to the literature on the subject (e.g., Demonel \& Marx, 2015; Taborda et al., 2013) that present MSE as not very innovative, it is possible to state that there are indications that the functional innovation system that promotes the promotion of innovation by MSE is to a certain extent present in the State of Piauí. Although in an incipient form, since MSE have innovation capacity between "Little Innovative" and "Occasional Innovative", leaving room for fundamental improvements in the degree of innovation, and that this capacity is homogenized for the MSE of the study, driven mainly by Organizational and Marketing Innovations. 


\section{CONCLUSION}

As mentioned above, the main objective of the current research was to verify how the innovation presents itself in the MSE of the State of Piauí using the model proposed by Walter, Veloso and Fernandes (2017).

For that the following research hypotheses were established: $\mathrm{H}_{1}$ : The Micro and Small Enterprises of the State of Piauí present themselves as little innovative; $\mathrm{H}_{2}$ : Innovation in Micro and Small Enterprises in the State of Piauí presents itself differently due to its business environments (Geographical Location and Sectors of Activity).

Overall, the MSE of the sample under study has innovation capacity between "Little Innovative" and "Occasional Innovative", since the Average Global Innovation Index (GAII) obtained through the average of the 13 dimensions of the applied Innovation Radar in the 617 MSE of the State of Piauí was 2,01 points (standard deviation 0,92 ). Since the classification usually adopted establishes that the final average score 1 (One) means "Little Innovative"; The final average score 3 (Three) means "Occasional Innovative" and the final average score 5 (Five) means "Systemic Innovative", it can be affirmed that the MSE of the sample under study have innovative capacity between "Little Innovative" and "Occasional Innovative", due to the preponderance of Organizational and Marketing Innovations, resulting in a non-validated the research hypothesis 1.

In order to verify in a general way how the GAll of the MSE presents as a result of the variables of control City, Activity Sectors, and Geographic Location, using inferential analyses, it was observed that the distribution of GAll is the same between Cities and that the GAll average is the same between activity sectors and geographic location. Because the distribution of GAll is the same among cities; of the innovation average is the same among the MSE of the Commerce and Services segments, as well as between the MSE in the interior and the capital, the second research hypothesis is also not validated, since there is enough statistical evidence to affirm that innovation It is homogenized for the MSE of the study, using the control variables City, Activity Sectors and Geographic Location.

The results obtained provide an important practical contribution to the management and monitoring of innovation in Micro and Small Enterprises in a given region by presenting an indicator that reflects how much innovation is present, serving as a parameter for potential improvements both by companies and by the public power. As theoretical contributions, the presented model leads to useful and systematic information on how innovation presents itself in Micro and Small Enterprises in a global way as a result of its business environments, and can thus be useful as a model that serves as a parameter for the Improvement of innovation through public policies aimed at improving the business environment that increase the degree of innovation of the companies that constitute it, and therefore validate the theoretical model in the case in question. Possible public policies are the establishment of partnerships with universities and local research institutes, with a view to obtaining the necessary resources for innovation, the formation of innovation networks between Micro and Small Enterprises and financial subsidies by the government for companies that join the innovation networks.

The limitations of the study are in the fact that the theoretical model presents useful information about how innovation presents itself in a global way, but it does not make it possible 
to identify in detail the types of innovation developed by the companies studied, considering the innovation as a homogeneous whole within a given business environment.

As future research, we intend to develop studies that identify the factors that determine the innovation in MSE using the geographical location as parameter, thus, we leave the present question: Are there differences in the factors that determines the innovation in MSE when are considered the Local Systems of Innovation?

\section{REFERENCES}

1. Akis, E. (2015). "Innovation and Competitive Power". Procedia-Social and Behavioral Sciences, Vol.195, pp. 1311-1320.

2. Aarstad, J., Kvitastein, O., \& Jakobsen, S. (2016). "Related and unrelated variety as regional drivers of enterprise productivity and innovation: A multilevel study". Research Policy, Vol. 45, pp. 844-856.

3. Bayarçelik, E., Tasel, F., \& Apak, S. (2014). "A Research on Determining Innovation Factors for SMEs”. Procedia - Social and Behavioral Sciences, Vol. 150, pp. 202-211.

4. Bachmann, D. L. (2011). Metodologia para determinar o radar da inovação nas pequenas empresas. Curitiba: (s.n.).

5. Boeddrich, H. J. (2004). "Ideas in the workplace: a new approach towards organizing the fuzzy front end of the innovation process". Creativity \& Innovation Management, Vol.13, No 4, pp.274-285.

6. Brem, A., \& Voigt, K.I. (2009). "Integration of market pull and technology push in the corporate front end and innovation management-insights from the German software industry". Technovation, Vol. 29, No 5, pp. 351-367.

7. Ceretta, G., Reis, D., \& Rocha, A. (2016). Inovação e modelos de negócio: um estudo bibliométrico da produção científica na base Web of Science. Gestão e Produção, 23(2), 433444.

8. Cooper, R. G. (1988). "The new product process: a decision guide for management". Journal of Marketing Management, Vol. 3, No 3, pp. 238-255.

9. Demonel, W., \& Marx, R. (2015). "Gestão da Cadeia de Valor da Inovação em ambientes de baixa intensidade tecnológica". Production, Vol. 25, No 4, pp. 988-999.

10. Flynn, M., Dooley, L., O'sullivan, D., \& Cormican, K. (2003). "Idea management for organisational innovation". International Journal of Innovation Management, Vol. 7, No 4, pp. 417-442.

11. Hamel, G., \& Sayago, A. (2007). Derrubando as muralhas que cercam a criatividade empresarial. Subtítulo em: Harvard Business School: Implementando a inovação. 29-39. Rio de janeiro: Elsevier.

12. Inan, G., \& Bititci, U. (2015). Understanding organizational capabilities and dynamic capabilities in the context of micro enterprises: a research agenda. Procedia-Social and Behavioral Sciences, 210, 310-319.

13. JUCEPI. (2015, 3 de Julho). Piauí registra crescimento na abertura de novas empresas. Acesso em: 15 de Outubro de 2016. Disponível em: http://www.jucepi.pi.gov.br/noticia.php?id=90 
14. Koen, P. A., Ajamian, G., Burkart, R., Clamen, A., Davidson, J., D'amore, R., Elkins, C., Herald, K., Incorvia, M., Johnson, A., Karol, R., Seibert, R., Slavejkov, A., \& Wagner, K. (2001). "Providing clarity and a common language to the "fuzzy front end"'. Research Technology Management, Vol. 44, No 2, pp. 46-55.

15. Khurana, A., \& Rosenthal, S. R. (1997). "Integrating the fuzzy front end of new product development”. Sloan Management Review, Vol. 38, No 2, pp. 103-120.

16. Kim,W., \& Mauborgne, R. (2005). A estratégia do Oceano Azul:como criar novos mercados e tornar a concorrência irrelevante. Rio de janeiro: Elsevier.

17. Kurkkio, M., Frishammar, J., \& Lichtenthaler, U. (2011). "Where process development begins: a multiple case study of front end activities in process firms". Technovation, Vol. 31, No 9, pp. 490-504.

18. Maroco, J., \& Marques, T. (2006). Qual a fiabilidade do alfa de Cronbach? Questões antigas e soluções modernas? Laboratório de Psicologia, 4(1), 65-90.

19. Neto, A., \& Teixeira, R. (2011). Mensuração do Grau de Inovação de Micro e Pequenas Empresas: Estudo em Empresas da Cadeia Têxtil-Confeç̧ão em Sergipe. XXXV ENANPAD, Rio de Janeiro, Setembro.

20. OCDE \& FINEP. (2005). Manual de Oslo. (3.ed.). Retirado de: <http://www.mct.gov.br/upd_blob/0011/11696.pdf>. Acedido em 02 de setembro de 2016.

21. Ornek, A., \& Ayas, S. (2015). The Relationship Between Intellectual Capital, Innovative Work Behavior and Business Performance Reflection. Procedia-Social and Behavioral Sciences, 195, 1387-1395.

22. Paredes, B., Santana, G., \& Fell, A. (2014). Um estudo de aplicação do radar da inovação: o grau de inovação organizacional em uma empresa de pequeno porte do setor metalmecânico. Revista de Gestão e Tecnologia, 4(1), 76-88.

23. Paula, C. (2014). Análise do grau de inovação das Micro e Pequenas Empresas do segmento alimentício atendidas pelo programa Agentes Locais de Inovação na Região Oeste do Estado de Goiás. (Dissertação de Mestrado, Faculdades Alves Faria, Goiânia, GO, Brasil).

24. Pereira, M., Grapeggia, M., Emmendoerfer, M., \& Três, D. (2009). "Fatores de inovação para a sobrevivência das Micro e Pequenas Empresas no Brasil". RAl - Revista de Administração e Inovação, Vol. 6, No 1, pp. 50-65.

25. Reichert, F., Camboim, G., \& Zawislak, P. (2015). “Capacidades e Trajetórias de Inovação de Empresas Brasileiras". Ram-Revista de Administração Mackenzie, Vol. 16, No 5, pp. 161-194.

26. Rodrigues, A. (2003). Cluster e Competitividade: um estudo da concentração de Micro e Pequenas Empresas de Alimentos no município de Marília/SP (Tese de Doutoramento, Universidade de São Paulo, São Carlos, SP, Brasil).

27. Rothwell, R. (1994). "Towards the fifth generation innovation process". International Marketing Review, Vol. 11, pp. 7-31.

28. Reid, S. E., \& Brentani, U. (2004). "The fuzzy front end of new product development for discontinuous innovations: a theoretical model". Journal of Product Innovation Management, Vol. 21, No 3, pp. 170-184.

29. Rojas, S., \& Carrillo, A. (2014). "Sistema para la evaluación de capacidades de innovación en 
pymes de países en desarrollo: caso Panamá". Revista Facultad de Ciencias Económicas, XXII No 2, Diciembre, pp. 109-122.

30. Šoltés, V., \& Gavurová, B. (2014). "Innovation policy as the main accelerator of increasing the competitiveness of small and medium-sized enterprises in Slovakia". Economics and Finance, Vol. 15, pp. 1478-1485.

31. Sibirskaya, E., Stroeva, O., \& Simonova, E. (2015). The Characteristic of the Institutional and Organizational Environment of Small Innovative and Big Business Cooperation. Economics and Finance, 27, 507-515.

32. Sawhney, M. Wolcott, R. C., \& Arroniz, I. (2006). The 12 Different Ways for Companies to Innovate. MIT, Spring.

33. Skibinski, A., \& Sipa, M. (2015). "Sources of Innovation of Small Businesses: Polish Perspective". Economics and Finance, Vol. 27, pp. 429-437.

34. Schreiber, D., Bessi, V., Puffal, D., \& Tondolo, V. (2013). Posicionamento estratégico de MPEs com base na inovação através do modelo hélice tríplice. Revista Eletrônica de Administração, 76(3), 767-795.

35. Tigre, P. (2006). Gestão da Inovação: a Economia da Tecnologia no Brasil. Rio de Janeiro: Elsevier.

36. Taborda, C., Estevão, C., \& Nunes, S. (2013). “A gestão da inovação nas PME's da Beira Interior: as perspetivas dos gestores". Tourism \& Management Studies, Vol. 9, No 2, pp. 124-129.

37. Whitney, D. E. (2007). "Assemble a technology development toolkit". Research Technology Management, Vol. 50, No 5, pp. 52-58.

38. Walter, C., Veloso, C., \& Fernandes, P. (2017). Innovation in Micro and Small Enterprises: a conceptual proposal for research. South American Development Society Journal, 3(08), 162 177. 